\title{
ANNUAL DEVELOPMENT OF GONADS OF PUMPKINSEED, LEPOMIS GIBBOSUS (ACTINOPTERYGII: PERCIFORMES: CENTRARCHIDAE) FROM A HEATED-WATER DISCHARGE CANAL OF A POWER PLANT IN THE LOWER STRETCH OF THE ODER RIVER, POLAND
}

\author{
Józef DOMAGAŁA*, Lucyna KIRCZUK, Katarzyna DZIEWULSKA, \\ and Małgorzata PILECKA-RAPACZ
}

Division of General Zoology, University of Szczecin, Poland

\begin{abstract}
Domagała J., Kirczuk L., Dziewulska K., Pilecka-Rapacz M. 2014. Annual development of gonads of pumpkinseed, Lepomis gibbosus (Actinopterygii: Perciformes: Centrarchidae) from a heated-water discharge canal of a power plant in the lower stretch of the Oder River, Poland. Acta Ichthyol. Piscat. 44 (2): 131-143.
\end{abstract}

Background. The pumpkinseed, Lepomis gibbosus (Linnaeus, 1758), known also as pumpkinseed sunfish, is native to eastern and central North America. Its introduction to Europe has resulted in fast spreading of the species over the continent. In Poland, the pumpkinseed has found favourable conditions for living and reproduction in water bodies artificially heated by thermal power plants. The aim of this study was to determine the annual cycle of gonad development of the pumpkinseed population inhabiting the warm-water canal of the Dolna Odra power plant (NW Poland), which has not been studied before at this location.

Materials and methods. The pumpkinseed individuals were caught in the heated-water discharge canal of the Dolna Odra power plant. The average water temperature in the canal was by $6-8^{\circ} \mathrm{C}$ higher than that of the river. The analysis of the annual cycle of gonad development was performed in both sexes using histological methods. The fish were aged $3+$ to $6+$. A standard paraffin technique and Heidenhain's iron hematoxylin staining were used. Results. In the site surveyed, the spawning season for females lasted from the beginning of May through August, i.e., was longer than in the native range of this fish species. In one female caught in September, the ovaries contained oocytes in the stage of vitellogenesis. The oocytes in the stage of atresia were found rarely in the fish caught from April through June. Mature testes in males were found between late April and September, i.e., throughout the spawning period of the females. Few male anomalies of the sexual cycle were observed, e.g., in October, they were found to engage in another cycle of spermatogenesis and spermatozoa production. Moreover, the presence of large groups of degenerating cells in the seminal tubules was observed throughout the year, but was particularly evident between September and February.

Conclusion. The results have confirmed the high colonisation abilities of the pumpkinseed. As a consequence of global warming, the studied canal with post-cooling water may become a starting point of expansion of this species to other bodies of water. Upon a considerable climate warming, this species could threaten the native species.

Keywords: reproductive cycle, oogenesis, spermatogenesis, post-cooling water

\section{INTRODUCTION}

The pumpkinseed, Lepomis gibbosus (Linnaeus, 1758), known also as pumpkinseed sunfish, is native to eastern and central North America (Tomeček et al. 2007). Because of its attractive appearance, the species was introduced to Europe in the 19th century as an ornamental fish for aquaria or park ponds, or a prospective sport fish (Vooren 1972, Witkowski and Grabowska 2012). Natural escapes and intentional introduction of the fish into open waters has resulted in fast spreading of the species over Europe and a successful colonisation. The pumpkinseed has been already found in at least 28 European countries and in Asia Minor (Coop and Fox 2007). The fish are found in shallow, weedy, quiet reservoirs, lakes, river inlets, tributaries, and canals, in cool to moderately warm waters (Miller 1963, Tomeček et al. 2007). The range of the species is limited by the water temperature. The optimum temperature for pumpkinseed growth is $20-30^{\circ} \mathrm{C}$ (Mischke and Morris 2002). For reproduction, they need the critical temperature range of $14-16.5^{\circ} \mathrm{C}$ (Burns 1976).

\footnotetext{
${ }^{*}$ Correspondence: Prof. Józef Domagała, Uniwersytet Szczeciński, Katedra Zoologii Ogólnej, ul. Felczaka 3c, 71-412 Szczecin, Poland, phone: +48 91 444-1616, fax +4891 444-1623, e-mail: (JD) jozef.domagala@univ.szczecin.pl, (LK) lucyna@univ.szczecin.pl, (KD) katarzyna.dziewulska@univ.szczecin.pl, (MPR) malgorzata.rapacz@univ.szczecin.pl.
} 
According to Gutiérrez-Estrada et al. (2000), pumpkinseed tolerates the temperatures as high as $36.6^{\circ} \mathrm{C}$. It has been determined that the pumpkinseed, similarly to other centrarchids, upon introduction into new habitats forms new populations that can differ in the rate of growth, age of reaching sexual maturity, and the lifespan. These features are related to the development of alternative life-history traits in these populations (Deacon and Keast 1987, Bertschy and Fox 1999, Villeneuve et al. 2005, Aday et al. 2006, Dembski et al. 2006, Tomeček et al. 2007, Cucherousset et al. 2009).

The pumpkinseed, Lepomis gibbosus, was intentionally introduced to Poland in 1927 (Witkowski and Grabowska 2012). The distribution of the species is limited to isolated locations. It was found in the Oder River and its tributaries, being particularly abundant in the lower stretch of the Oder River, below the Dolna Odra power plant (Heese and Przybyszewski 1985, Witkowski et al. 2004, Witkowski and Grabowska 2012). Other sites, less populated by L. gibbosus include isolated lakes, ponds, and impounding reservoirs (Witkowski 1979, 2002). The species expansion towards other bodies of water is restricted by lower temperature (Copp and Fox 2007). Similar tendencies have been observed in cooler habitats in England, where the species does not spread and many of its populations decrease (Lever 1977). In relation to the global warming, such observation may prove interesting by indicating a possible expansion of the species in the future. In Europe, the pumpkinseed is treated as an invasive species, quickly spreading over open waters and demonstrating a high potential for acquiring new habitats (Witkowski 2002). The pumpkinseed has found favourable conditions for living in the warm-water canal the Dolna Odra power plant, and established there a self-sustained population. The Dolna Odra power plant discharges post-cooling waters to the warm-water canal where the effective water temperature is by $6-8^{\circ} \mathrm{C}$ higher than that of the neighbouring Oder River. In the warmest months the water temperature reaches $26-30^{\circ} \mathrm{C}$ (Domagała and Kondratowicz 2005, Domagała and Pilecka-Rapacz 2007). However, no data on the reproductive potential of the population established in this new environment have been published. The reproduction cycle of the pumpkinseed populations from other areas has also been studied only occasionally, usually without using the most accurate tools available for this purpose, i.e., histological ones. As yet, only few authors have studied the reproductive cycle of the pumpkinseed based on analyses of histological structures (Burns 1976). Some of these analyses provided limited information (De
Magalhães et al. 2005, Santos et al. 2012). In the majority of studies, the information on the reproductive cycle was based on the values of gonadosomatic index (GSI) (Fox and Keast 1991, Danylchuk and Fox 1994, Neophitou and Giapis 1994, Dembski et al. 2006, Santos et al. 2012) and concerned mainly females (Fox 1994, Fox and Crivelli 1998, 2001). Other studies were based on the observations of the morphology of gonads (Deacon and Keast 1987), changes in gonad weight (Dembski et al. 2006), nesting (Danylchuk and Fox 1994), or the size distribution of larvae (Vila-Gispert and Moreno-Amich 1998, 2000). The aim of this study was to determine the annual cycle of gonad development in the pumpkinseed individuals from the self-sustained population living in the warm-water canal discharge canal of the Dolna Odra power plant, using histological analyses.

\section{MATERIALS AND METHODS}

The presently reported study was carried out in the heated-water discharge canal of the Dolna Odra power plant, Nowe Czarnowo, near Gryfino, NW Poland $\left(53^{\circ} 11^{\prime} \mathrm{N}, 14^{\circ} 29^{\prime} \mathrm{E}\right)$. Dolna Odra is a thermal power station based on combustion of coal, being the principal energy source in Poland. The turbines require constant cooling. The cooling medium is water from the nearby East Oder River (Odra Wschodnia). The post-cooling water is discharged into the warm-water canal, which is some $4 \mathrm{~km}$ long. The canal hosts a self-established population of pumpkinseed, Lepomis gibbosus, which we targeted in this study. The pumpkinseed range is limited to the canal and the fish can only occasionally be found below the merging point of the canal and the river.

From September 2007 through August 2008 we surveyed pumpkinseed from the canal one- to four times a month and a total of 196 females and 224 males were caught (Table 1). The total length (TL) of the fish was measured to the nearest $0.1 \mathrm{~mm}$, and their body weight determined to the nearest $0.1 \mathrm{~g}$. Their gonads were dissected and fixed in the Bouin solution. The fish age was determined based on the analysis of rings on the collected scales. The fixed gonads were weighed with the accuracy of $0.1 \mathrm{mg}$. Two parameters were calculated: the Fulton condition factor $(K)$ and the gonadosomatic index (GSI) using the respective formulas:

$$
\begin{aligned}
& K=100 W_{\mathrm{g}} \cdot \mathrm{TL}^{-3} \\
& \text { and } \\
& \mathrm{GSI}=100 W_{\mathrm{g}} \cdot W_{\mathrm{b}}^{-1}
\end{aligned}
$$

where: $W_{\mathrm{g}}$ is the gonad weight $[\mathrm{g}], W_{\mathrm{b}}$ is the total fish weight [g], and TL in the total length of fish [cm].

\begin{tabular}{|c|c|c|c|c|c|c|c|c|c|c|c|c|c|}
\hline \multirow{2}{*}{ Sex } & \multicolumn{12}{|c|}{ Number of fish per month } & \multirow[t]{2}{*}{ Total } \\
\hline & Sep & Oct & Nov & Dec & Jan & Feb & Mar & Apr & May & Jun & Jul & Aug & \\
\hline Female & 7 & 20 & 16 & 6 & 22 & 20 & 25 & 21 & 11 & 13 & 27 & 8 & 196 \\
\hline Male & 16 & 19 & 20 & 66 & 20 & 20 & 16 & 18 & 17 & 25 & 27 & 20 & 224 \\
\hline
\end{tabular}

Table 1

Number of pumpkinseed, Lepomis gibbosus, specimens sampled from September 2007 through August 2008 
All gonads were studied histologically. Fragments of $0.5 \mathrm{~cm}$ were cut out from the middle part of the gonad and processed using a standard paraffin technique. Five- $\mu \mathrm{m}-$ thick sections were regressively stained with Heidenhain's iron hematoxylin. The histological slides were analysed under Nikon Eclipse 80i light microscope. The measurements and photographic documentation were made using Nikon DS-5Mc-U2 digital camera (5 megapixels) and further processed with NIS Elements 3.20 computer software.

There were three principal reasons for doing histological evaluation of female gonads of Lepomis gibbosus:

- Determining their maturity (the modified 6 degree scale applied in Domagała et al. (2013);

- Determining the size of oocytes in particular stages of development and in particular months;

- Identifying the number of degenerating oocytes.

We made the following histological measurements:

- The best developed oocytes from the gonads in the highest stage of development for a given month ( 5 females from each site, 30 measurement in one gonad);

- Oocytes from each stage of development from all sites (10 gonads representing each stage, 30 measurements in one gonad),

- Oocyte size in vitellogenesis in the stage of vacuolisation, yolk accumulation and completion of vitellogenesis.

The measurements were made to the nearest of $0.01 \mathrm{~mm}$. The oocyte diameter was calculated from measurements of the longest and shortest diameters of the mid cross section of the oocyte (Hunter and Goldberg 1980).

The sexual cycle of males was described using modified 6-stage scale proposed by Sakun and Buckaâ (1963):

- Stage 1: type A spermatogonia occurring in seminal tubules; small amounts of residual spermatozoa from the previous cycle can also be found;

- Stage 2: cysts with type B spermatogonia occurring in seminal tubules; small amounts of residual spermatozoa from the previous cycle can also be found;

- Stage 3: primary spermatocytes (early stage 3) and consecutive cells of the spermatogenesis (late stage 3) appearing in seminal tubules; the first spermatozoa can be found, efferent duct without spermatozoa;

- Stage 4: spawning testis, seminal tubules containing cysts with cells representing all spermatogenetic stages (from spermatogonia type B to spermatozoa), efferent duct filled up with milt;

- Stage 5: gonads with finalized spermatogenesis, seminal tubules filled with numerous spermatozoa, no younger spermatogenetic cells were observed (or were observed sporadically), efferent duct filled up with milt;

- Stage 6: spent gonads, seminal tubules containing small number of residual spermatozoa, efferent duct may contain spermatozoa;

- Stage 6-1: only type A spermatogonia occurring in tubule wall;

- Stage 6-2: type A spermatogonia and cysts with type B spermatogonia of next cycle start forming adjacent to the tubule wall.
Statistical analysis. The non-parametric multiple comparison ANOVA Kruskal-Wallis test was used to test significance of differences in length and weight of fish, Fulton condition factor $(K)$, gonad weight, gonadosomatic index (GSI), oocyte size between the fish samples collected each month. All analyses were performed at significance level of 0.05 using the Statistica ${ }^{\circledR}$ v.10 software.

\section{RESULTS}

Principal somatic parameters of female. The age of pumpkinseed females ranged from $3+$ to $5+$. The mean length and weight were $13.0 \pm 1.98 \mathrm{~cm}$ (mean \pm standard deviation) and $49.7 \pm 25.17 \mathrm{~g}$, respectively. All females studied were over $8 \mathrm{~cm}$ in length and exceeding $9.70 \mathrm{~g}$ in weight. The Fulton condition factor was $2.1 \pm 0.32$. There were no significant differences between the fish caught in different months (Kruskal-Wallis test, $P>0.05$ ) (Fig. 1A, B) while Fulton condition factor fluctuated slightly (Fig. 1C). The weight of gonads, and GSI of the females were the highest from May through August, in the spawning season, and the values of these parameters differed significantly from the values obtained in the other months (Kruskal-Wallis test, $P<0.05$ ) (Fig. 1D, E).

Principal somatic parameters of male. The age of pumpkinseed males ranged from $3+$ to $6+$. The smallest adult male was $10.0 \mathrm{~cm}$ long. The mean length and weight of the males studied were $13.5 \pm 1.65 \mathrm{~cm}$ and $55.0 \pm 21.04 \mathrm{~g}$, respectively. The Fulton condition factor was $2.1 \pm 0.31$ on average. The length, weight, and the condition factor of the fish caught in all months were similar (Kruskal-Wallis test, $P>0.05$ ) (Fig. 2A, B, C). The weight of gonads and gonadosomatic index of sexually mature fish revealed fluctuations corresponding to the reproductive cycle, which is illustrated in Fig. 2D, E. The highest values of the two parameters were found from May through September (mean values varied from 0.45 to 1.11 ), while the lowest values were noted from October through March (mean values varied from 0.09 to 0.24 ) (Fig. 2D, E). The GSI values in individual males measured throughout the whole reproductive period varied from 0.03 to 2.57 .

Reproductive cycle of female. As shown by the histological analysis of pumpkinseed female gonads, the spawning season of this species in the post-cooling water discharged from the power plant lasted from May through August. The females caught in September had ovaries at the beginning of stage 3. On the slides of these gonads the majority of oocytes were in the stage of pre-vitellogenesis or at the beginning of vitellogenesis with a few drops of fat. Some females still had the degenerating oocytes left unexpelled after the spawning season. One female caught in September had ovaries with oocytes in the final stage of vitellogenesis (oocyte diameter $300-625 \mu \mathrm{m})$ (Fig. 3A). From October to the middle of February, the gonads were still at stage 3 . In the females caught in this period the contribution of oocytes in early vitellogenesis with oocytes having a small number of fat drops in cytoplasm was gradually increasing relative to those in previtellogenesis. Starting from the middle of February, yolk began to accumulate in oocytes (oocyte diameter $217.3 \mu \mathrm{m}$ ) 
of single individuals and in the other females the oocytes were still at the beginning of vitellogenesis (Fig. 3B). In March the accumulation of yolk became more intensive, in particular by the end of March. In April all ovaries in all females were at stage 4 , which means that they were filled with oocytes at the stage of finalised vitellogenesis (Fig. 3C). The changes in size of the oocytes at particular stages of the annual cycle of pumpkinseed are illustrated in Table 2. In May some females still had gonads at stage 4 that is oocytes with drops of fat and yolk (Fig. 3D). The

A
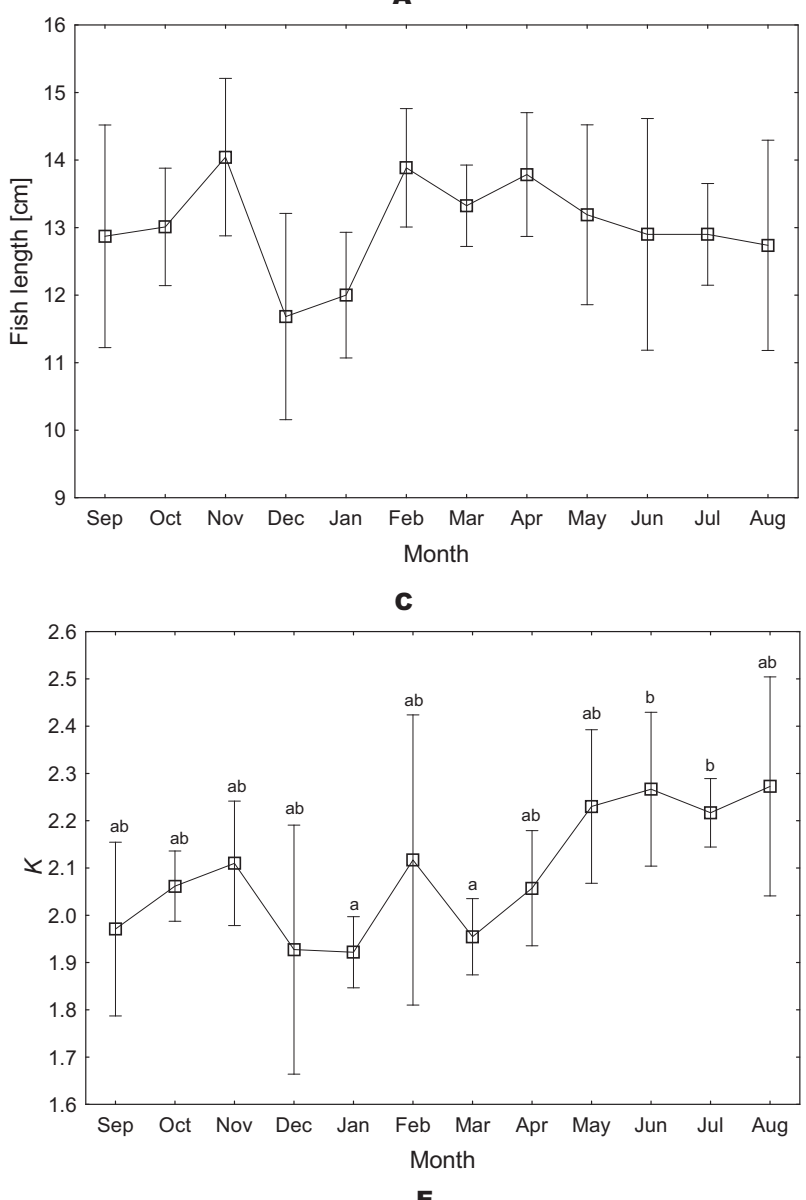

E

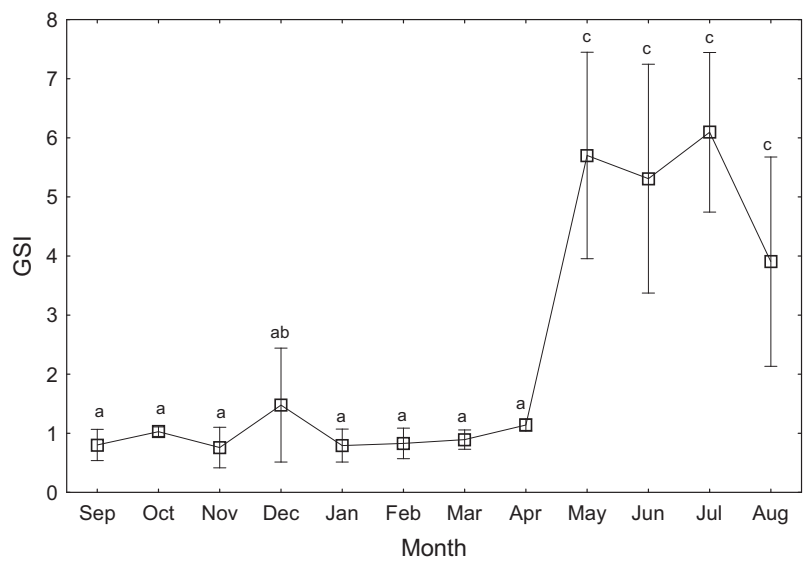

other ones had gonads in the final stage of vitellogenesis, gonads at stage 5 , oocytes with accumulated yolk and the nucleus at the pole. In June, an increased number of females were finalising vitellogenesis and some females had already spawned (Fig. 3E). In addition to the oocytes in the stage of vitellogenesis, all gonads collected in that month contained oocytes in pre-vitellogenesis that would mature and be laid in subsequent portions. Ovaries of pumpkinseed caught in July were in different stages:

- With oocytes only in pre-vitellogenesis;
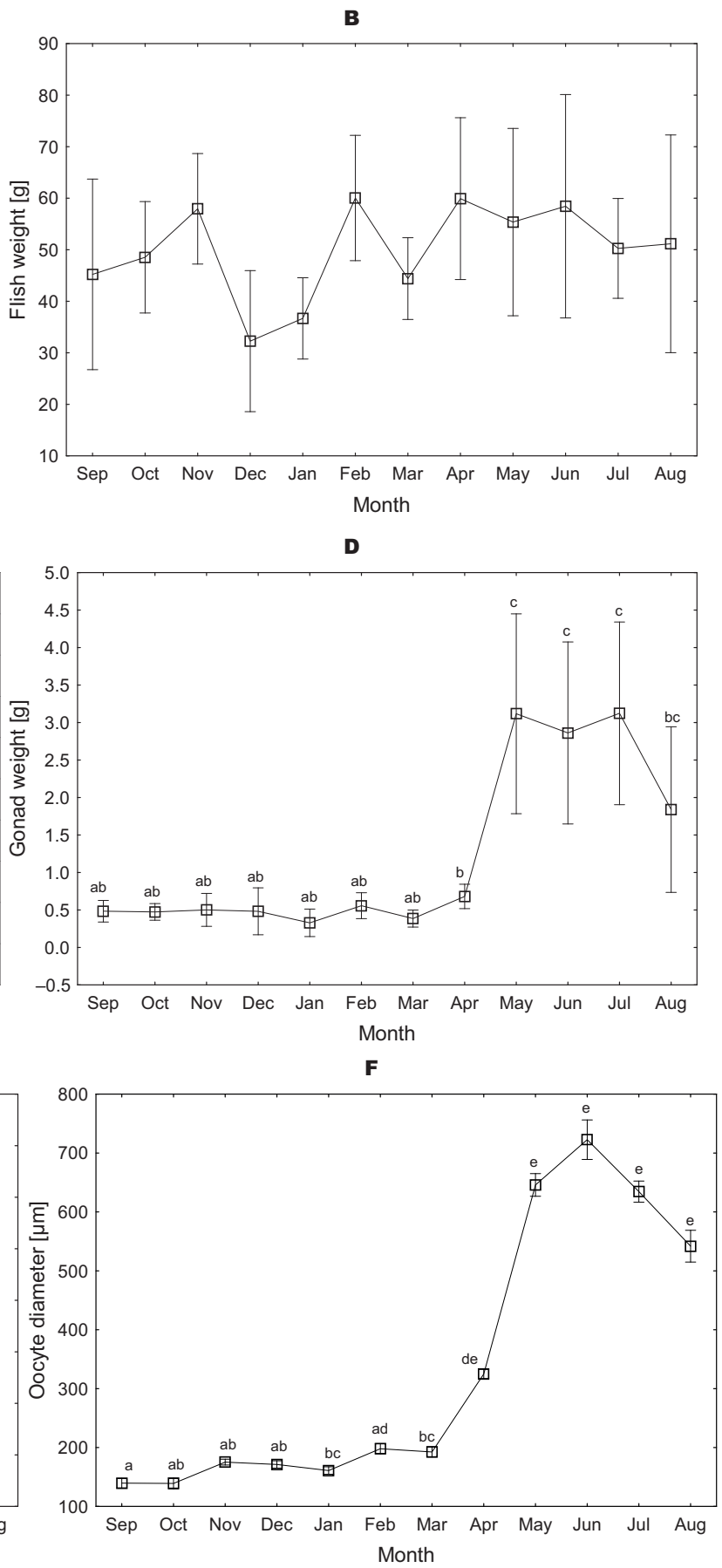

Fig. 1. Monthly distribution of female somatic parameters of pumpkinseed, Lepomis gibbosus; A: Total length (TL) of fish; B: Total weight of fish; C: Fulton condition factor $(K)$; D: Gonad weight $\left(W_{\mathrm{g}}\right)$; E: Gonadosomatic index (GSI); F: Diameter of the most developed oocytes; Values (mean \pm standard deviation) marked with different letters shows significant differences between each month parameters $(P<0.05$; ANOVA Kruskal-Wallis test) 
- With oocytes at different stages of vitellogenesis - only with drops of fat;

- With drops of fat and yolk;

- Finalising vitellogenesis;

- Post-spawning gonads.

In August some females had post-spawning oocytes in stage 6, with atresia of unexpelled oocytes (Fig. 3F), and with oocytes in pre-vitellogenesis. The other females caught in August had gonads filled with oocytes at the beginning of vitellogenesis (drops of fat) and finalising this process (drops of fat and yolk). The spawning season from May to August is indicated by the histological image of oocytes and high values of GSI in these months together with the largest sizes of the most developed oocytes noted in this period, $909.0 \mu \mathrm{m}$ in diameter (Fig. 1F). Fresh
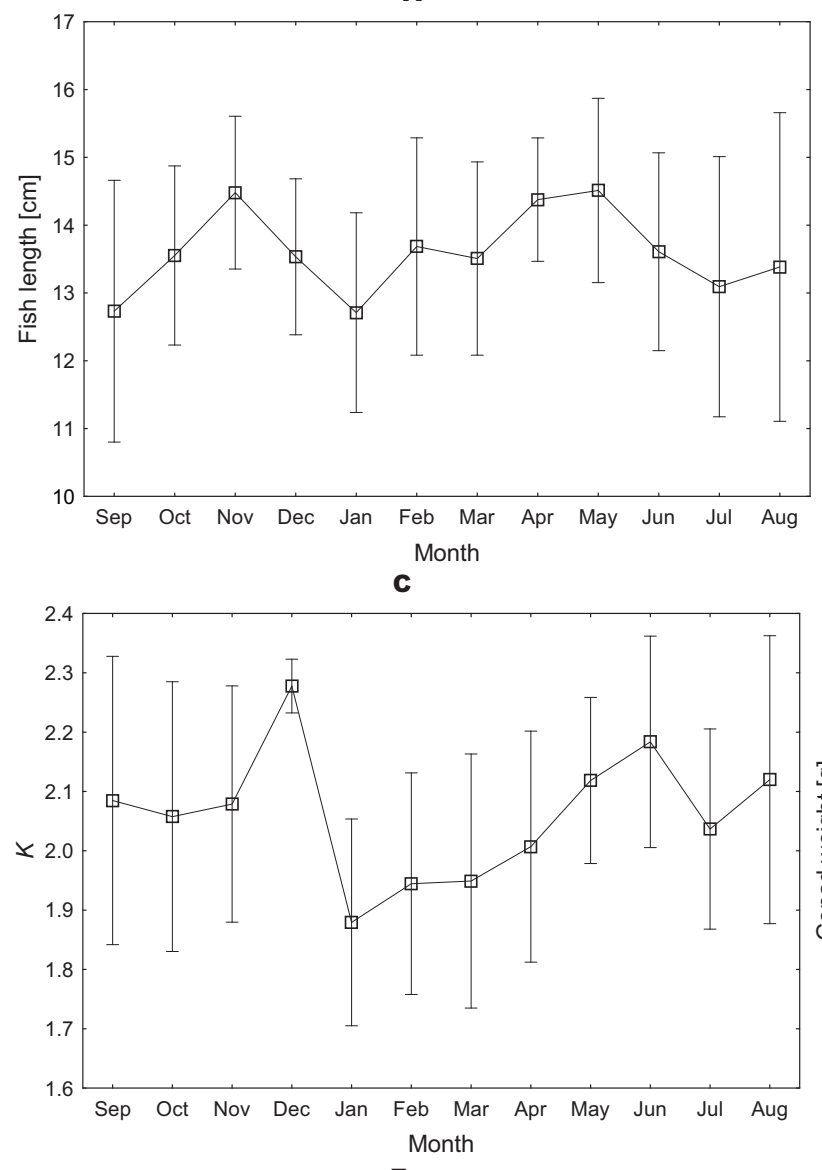

E

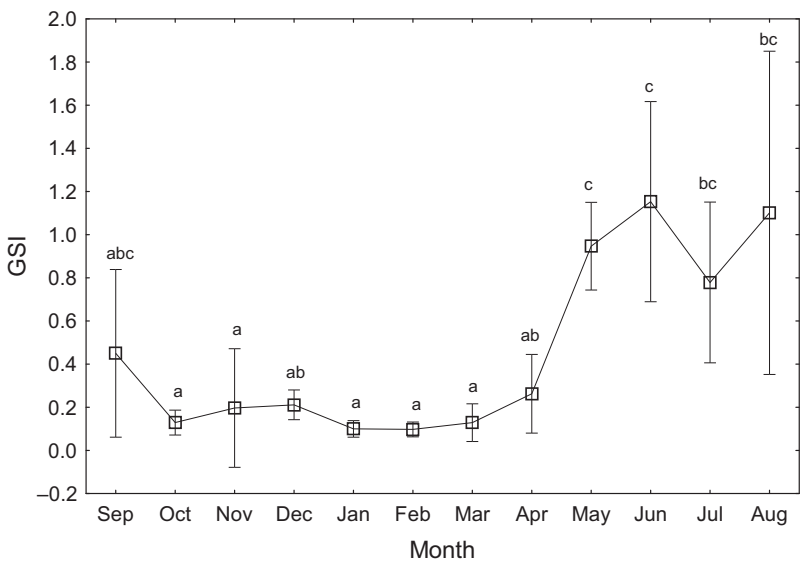

oocytes collected from gonads ready for spawning had the diameters from 884.5 to $1251.5 \mu \mathrm{m}$ (Table 2). In the fish caught in all months of the spawning season the ovaries had maturing oocytes at the stage of pre-vitellogenesis and vitellogenesis and post-spawning ones. The pre-spawning gonads contained oocytes that would probably mature and be laid in subsequent portions in the spawning season. The presence of oocytes in the final stage of vitellogenesis and post-spawning ones over the four months of the spawning season indicates that the spawn is laid in many portions. Detail analysis of this problem would need more frequent catchment of females in this season. The course of sexual cycle in female pumpkinseed expressed by percentage contribution of gonads at different stages of maturity in particular months of the calendar year is presented in Fig. 4.

B
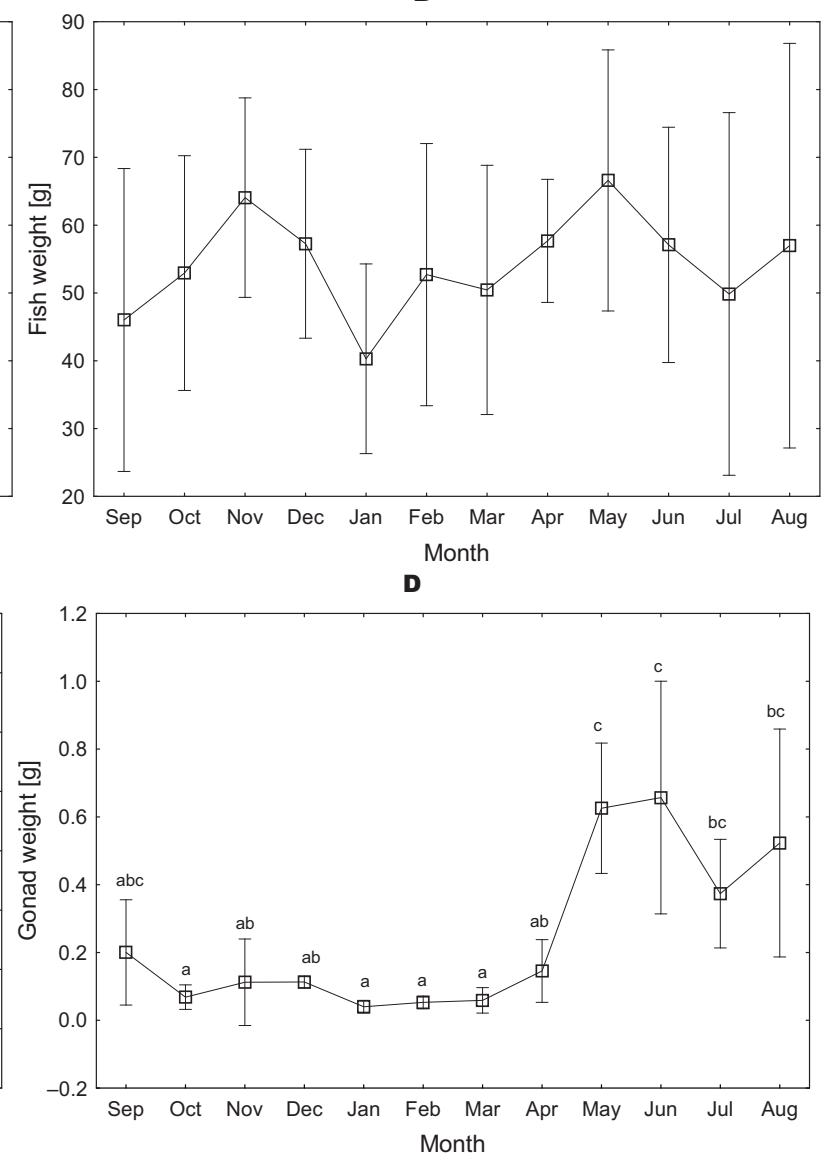

Fig. 2. Monthly distribution of male somatic parameters of pumpkinseed, Lepomis gibbosus: A: Total length (TL) of fish; B: Total weight of fish; C: Fulton condition factor $(K)$; D: Gonad weight $\left(W_{\mathrm{g}}\right)$; $\mathbf{E}$ : Gonadosomatic index (GSI); Values (mean \pm standard deviation) marked with different letters shows significant differences between each month parameters $(P<0.05$; ANOVA Kruskal-Wallis test $)$ 

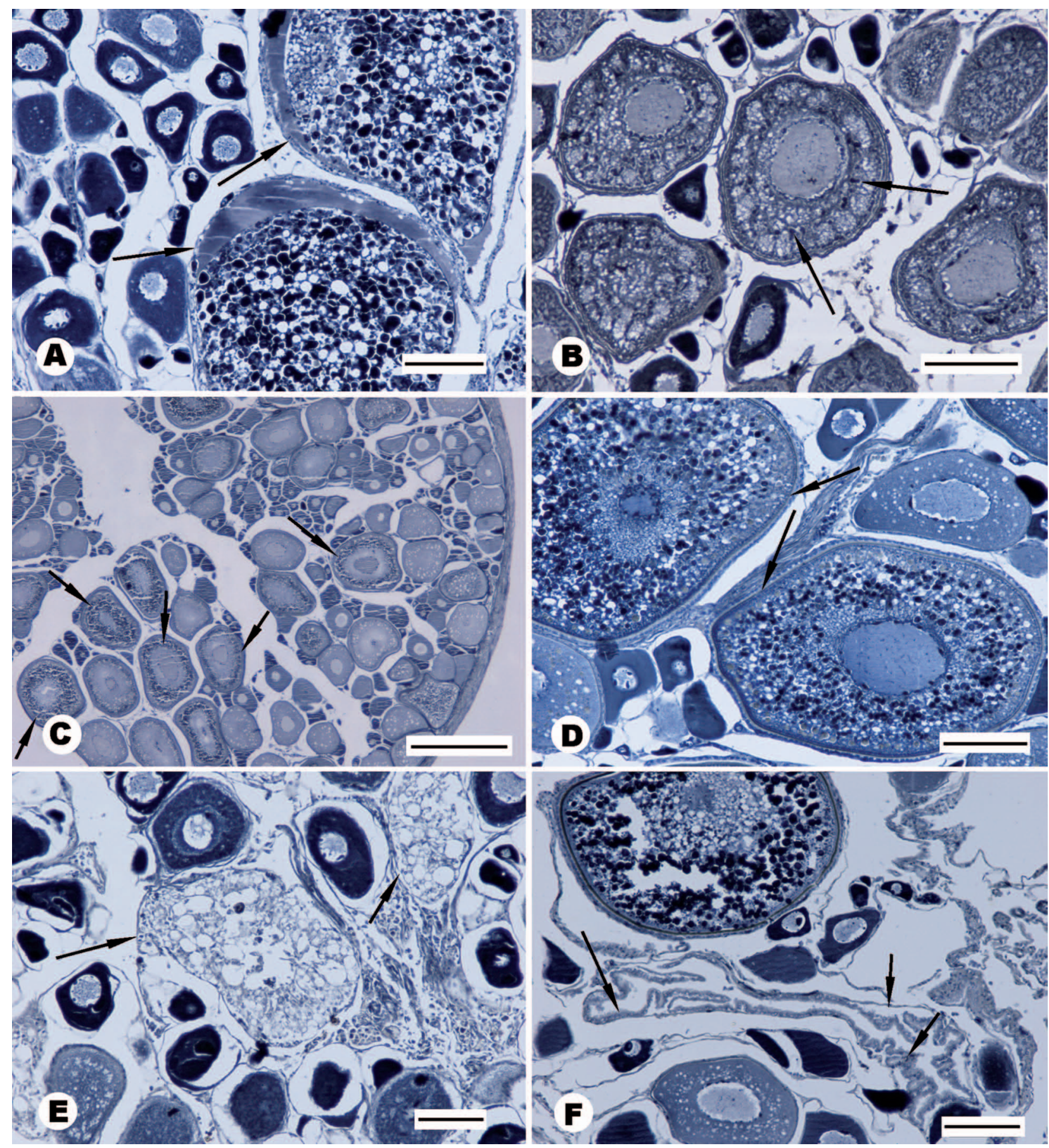

Fig. 3. Gonad of female pumpkinseed, Lepomis gibbosus; A: Advanced vitellogenesis (arrows), September; B: Beginning of vitellogenesis, drops yolk (arrows), February; C: Vitellogenesis (arrows), April; D: Vitellogenesis (arrows) May; E: After spawning (arrows), June; F: Atresia of unexpelled oocytes August; Scale bars $[\mu \mathrm{m}]: 100(\mathbf{A}, \mathbf{B}, \mathbf{E}, \mathbf{F}),, 500(\mathbf{C})$

Table 2

Sizes of oocytes at different stages of vitellogenesis of pumpkinseed, Lepomis gibbosus, from the warm-water canal of the Dolna Odra power plant

\begin{tabular}{cccccc}
\hline \multicolumn{7}{c}{ Oocyte size in respective stages of development } \\
\hline Stage 1 & Stage 2 & Stage 3 & Stage 4 & Stage 5 & Stage 6 \\
\hline $82.8 \pm 14.22$ & $161.8 \pm 33.35$ & $263.8 \pm 15.56$ & $456.6 \pm 15.56$ & $740.5 \pm 51.98$ & $997.3 \pm 126.52$ \\
$56.83-116.06$ & $105.20-235.91$ & $238.25-286.78$ & $288.73-676.86$ & $682.53-909.02$ & $884.52-1251.51$ \\
\hline
\end{tabular}

The values $[\mu \mathrm{m}]$ represent mean \pm standard deviation, as well as the range; Stage $1=$ pre-vitellogenesis (homogeneous cytoplasm); Stage 2 = beginning of vacuolisation; Stage 3 = first occurrence of yolk; Stage $4=$ finalization (central position of nucleus); Stage 5 = fusion of yolk, polar position of nucleus; Stage $6=$ spawn. 
Reproductive cycle of male. The male of pumpkinseed were ready to spawn from late April to September although under the condition of warm canal the individual males could restart the production of spermatozoa in next month. In October, after the spawning season, some males with tubules containing developing spermatozoa precursory cells (stage 3 ) or they were in the processes of spermatozoa production (stage 4$)$ were found $(30 \%$, Fig. 5A, B). These gonads had numerous groups of degenerating cells (Fig. 5A, B). In October, the majority of males had postspawning gonads with different amount of not expelled spermatozoa and presence of cysts with multiplying type B spermatogonia containing from 3 to 8 cells in the cyst cross-section (stage 2, 40\%, stage 6-2, 20\%) (Fig. 6A). In November and December, development of B type spermatogonia was observed (stage 2), and in a few tubules some small amounts of spermatozoa remaining from the previous cycle were found (stage 6-2). In the same months, numerous groups of degenerating cells were also present in the gonads (Fig. 5C). Such groups of degenerating cells were observed throughout the whole year but with lower intensity. In January, the cytological image of gonads of all males revealed developing cysts with type B spermatogonia present in tubules. The cross-section of the cysts shows $3-12$ cells. In about $40 \%$ of individuals the spermatozoa remaining from the previous season were found. In February, the histological image of gonads was similar. The number of cysts with type B spermatogonia was higher, the cross-section of a cyst revealed up to 20 cells (Fig. 6B). In March in about half of the males the cysts contained primary spermatocytes (stage 3) (Fig. 6C), the rest of the males were still at stage 2 . In single individuals very small numbers of spermatozoa left from the previous season were found moved to the seminal duct. At the beginning and middle of April, the gonads of all males were at stage 3 (Fig. 6D). From the end of April to August, the gonads in all males caught were ready to spawn achieved stage 4. The gonads were filled with tubules containing spermatozoa and cysts with all spermatogenetic cells. In the reproductive period, new spermatozoa were formed successively and were moved towards the seminal duct (Fig. 6E). In September in the majority of males, the tubules and seminal duct were filled with spermatozoa. In the tubule wall almost only type A spermatogonia were found. The tubules did not contain cysts with spermatozoa precursor cells or their sporadic amount (stage 5; 60\%) (Fig. 6F). Numerous groups of degenerating cells were often observed. Some males had post-spawning gonads (stage 6 and 6-2, 20\%) containing small number of spermatozoa (Fig. 6G). Also in September, some of males (20\%) started multiplication of type A and B spermatogonia, mainly in the apical part of the tubule (stage 2). The course of sexual cycle in male pumpkinseed expressed by percentage contribution of gonads at different stages of maturity in particular months of the calendar year is presented in Fig. 7.

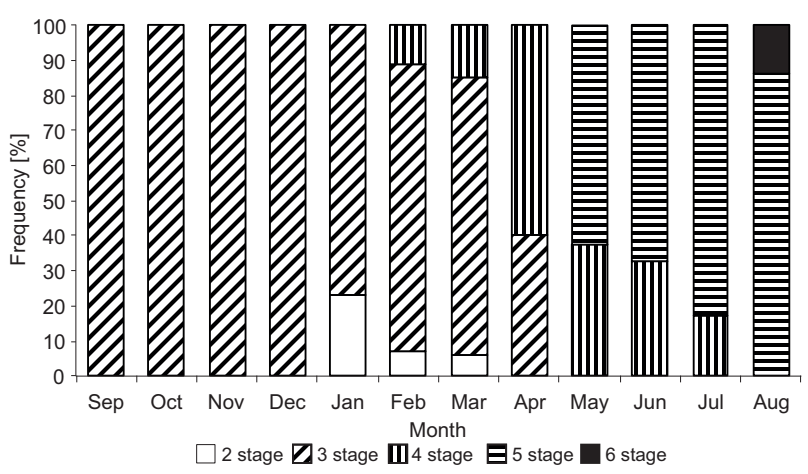

Fig. 4. Percentage contribution of gonads of respective maturity stages among females of pumpkinseed, Lepomis gibbosus, in consecutive months of the survey carried our in the warm-water canal of the Dolna Odra power plant

\section{DISCUSSION}

The elevated temperature in the canal with the postcooling water from the Dolna Odra power plant modifies the living conditions making them suitable for thermophilic organisms. The pumpkinseed introduced into the heated-water canal adapted very well to its parameters and formed a self-sustained population. The body sizes of pumpkinseed individuals living in the warm-water canal (in corresponding age groups) were greater than those of the fish living in their natural range in North America (Coop and Fox 2007). Their maximum length was greater than that reported for the European and Canadian fish and close to that of the fish caught at some habitats in North America (Danylchuk and Fox 1996, Gutiérrez-Estrada et al. 2000, Klaar et al. 2004, Coop et al. 2005). In different environments, the indigenous North American and the non-indigenous European pumpkinseed exhibit a high degree of variation in growth. In the Mirgenbach Reservoir in France, the fish living in a proximity of a nuclear power form early-maturing populations (Dembski et al. 2006). No dwarf forms were observed in the studied fishes from the warm-water canal of the Dolna Odra power plant.

Many features of the environment, such as water temperature, $\mathrm{pH}$, and water level, contribute to the commencement of the pumpkinseed spawning season (Neophitou and Giapis 1994). The course and duration of spawning of this species depend mainly on the photoperiod and temperature (Miller 1963), with temperature being the more important factor (Burns 1976). In the natural range of distribution, the pumpkinseed spawning season lasts from mid-May until July, and in some reservoirs, until the beginning of August (Breder 1936, Burns 1976, Fox 1994; Danylchuk and Fox 1994, 1996). As regards the European populations, the spawning season in Slovakia lasted from the end of May until the end of June (Holčik 1995), in Greece-from the second half of June until the end of July (Neophitou and Giapis 1994). In the north east region of Spain, the spawning season of this species was slightly longer and lasted from mid-May to 
mid-August (Vila-Gispert and Moreno-Amich 1998, 2000), while in the south of Spain, the spawning season spanned from April to August or early September (Gutiérrez-Estrada et al. 2000). A long spawning season, from early spring to August, has been also observed in the reservoirs with the post-cooling water from the Mirgenbach power plant in south-east France, in which the mean annual temperature was by $3.7^{\circ} \mathrm{C}$ higher than that of the water supplied to the power plant (Dembski et September.
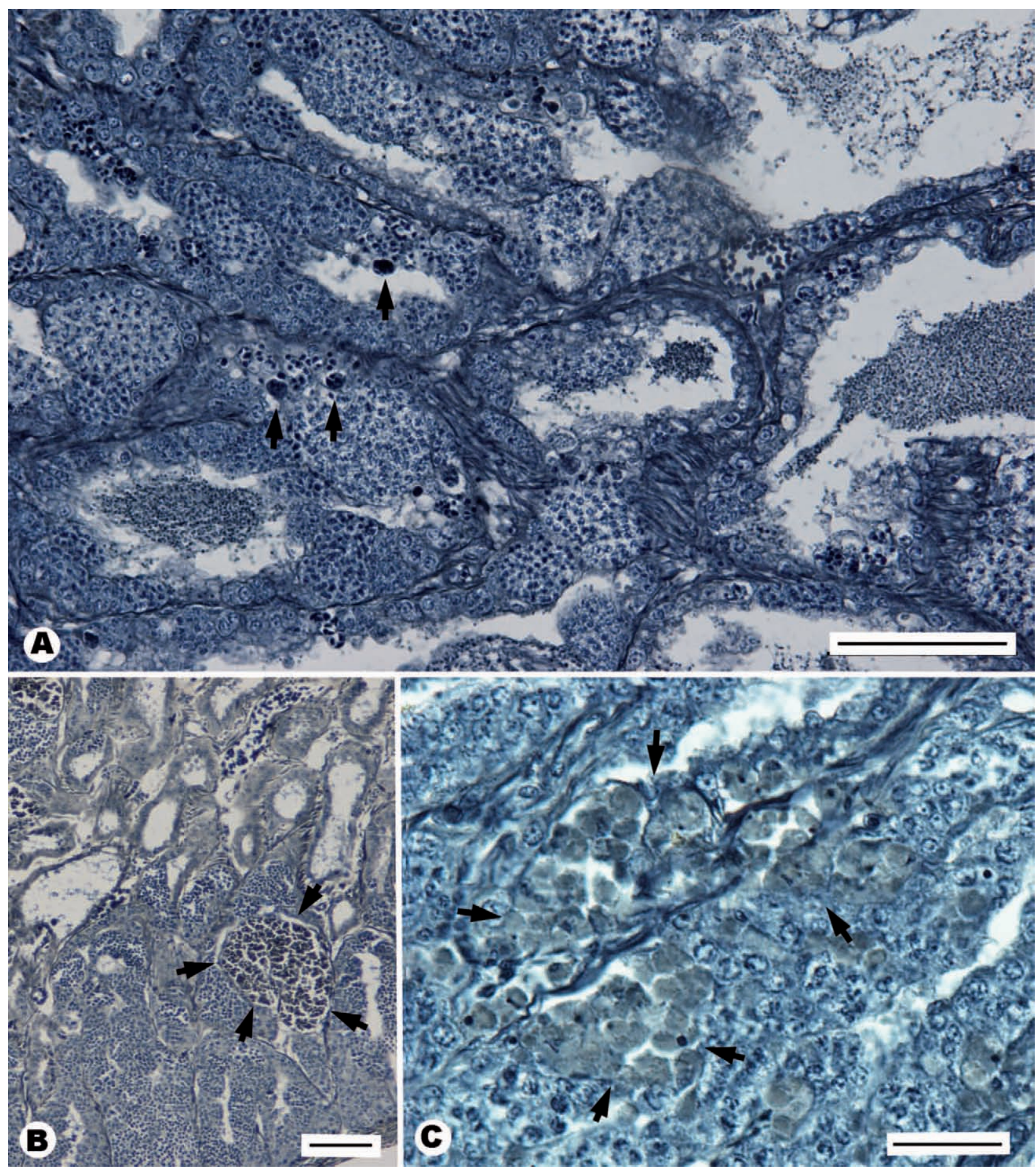

Fig. 5. Gonad of male pumpkinseed, Lepomis gibbosus; A: Stage 4 after spawning season; spermatozoa in tubule lumen, near tubule wall some cysts with cells representing all stages of spermatogenesis series; groups of degenerating cells visible (arrowhead), October; B: Stage 3; tubule with large group of degenerating cells (arrowhead); C: Stage 2; numerous small groups of degenerating cells (arrowhead) among spermatogonia; Scale bars $100 \mu \mathrm{m}$ 
The gonad weight and GSI of the fish revealed fluctua- In the fish from the Guadiato River (south Spain) (Gutiérreztions corresponding to the reproductive cycle. The studied Estrada et al. 2000) and North America (Burns 1976), females were characterised by a high GSI from May to the pumpkinseed reached the highest GSI at the beginning August, i.e., during the spawning season, similarly as in the of the spawning season, in April (Gutiérrez-Estrada et fish from the south of France (Crivelli and Mestre 1988). al. 2000) and July (Burns 1976). The females charac-
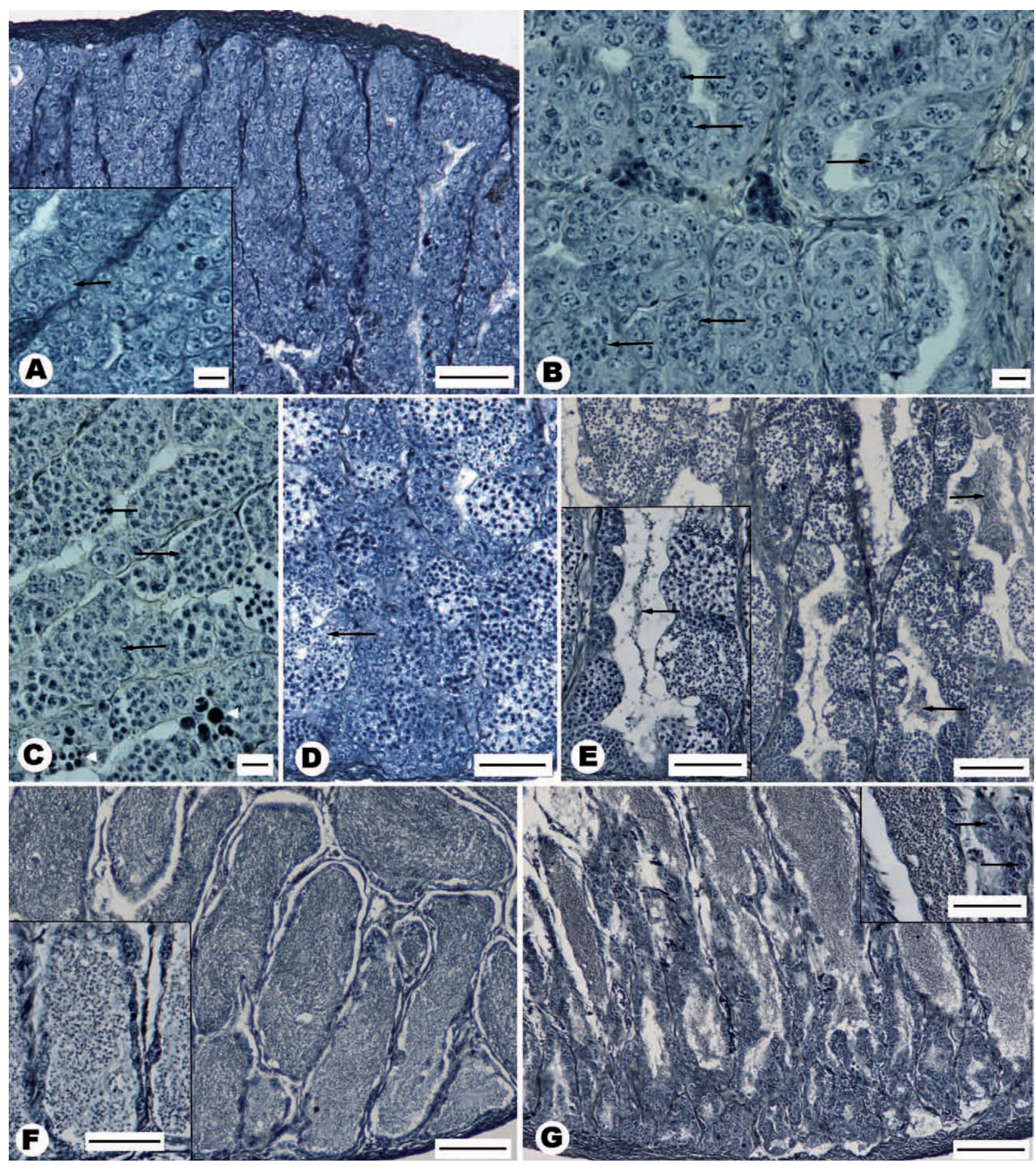

Fig. 6. Male gonad of pumpkinseed, Lepomis gibbosus; A: Early stage 2; tubules with few cysts containing type B spermatogonia (arrow); B: Stage 2; numerous cysts with type B spermatogonia (arrow); C: Early stage 3; tubules with numerous cysts containing primary spermatocytes (arrow); D: Late stage 3; numerous cysts with cell from spermatogonia B to spermatid (arrow); E: Ripe, stage 4; all cells of spermatogenesis present; spermatozoa in tubule lumen (arrow); F: Ripe, stage 5; tubules filled with spermatozoa; tubule wall containing only type A spermatogonia; G: Spent, stage 6-2; shrunken tubules filled with unexpelled spermatozoa; Tubule wall containing type A spermatogonia and cysts with type B spermatogonia (arrow); Scale bars $[\mu \mathrm{m}]: 10$ (A inset, B, C), 20 (D and insets of $\mathbf{E}, \mathbf{F}, \mathbf{G}), 100(\mathbf{E}, \mathbf{F}, \mathbf{G})$ 
terised by GSI $<2$ in the late spring were probably immature prior to the end of the spawning season (Dembski et al. 2006). The highest GSI in the analysed females from the warm-water canal was 12.7 , while, in the fish studied by (Burns 1976) it amounted to 10. In the fish from England it was close to 7 (Coop and Fox 2007), in Greece - close to 11 (Neophitou and Giapis 1994), and in the fish from the South of Spain, it was 15 (GutiérrezEstrada et al. 2000). In males, the lowest GSI values were noted from October to March (variation range between 0.09 and 0.21 ). The highest values of both gonad weight and GSI were observed from May to September; the GSI values varied from 0.5 to 1.1 , with the maximum individual value of 2.6. A similar annual distribution of gonad weight in males was reported by Dembski et al. (2006) for the fish living in a reservoir adjacent to a nuclear power plant in France. In Greece (Neophitou and Giapis 1994) and North America (Burns 1976), the high values of GSI for the same species were noted for a one-month shorter period. The mean GSI values in the spawning and postspawning seasons, similar to those obtained in the population we studied were reported by Neophitou and Giapis (1994) for a population in Greece, and by Burns (1976) for a population in North America. Dembski et al. (2006), who studied the population living in a reservoir adjacent to a nuclear power plant in France, reported the highest GSI values for males of the species, reaching 16, but these were precocious males that suffered from high mortality rates just after their first reproduction. When the GSI values obtained for both sexes were compared during the year, it was observed that in males, higher GSI values are obtained early and then maintained for a period of time longer than in females (Neophitou and Giapis 1994).

The pumpkinseed roe is laid in three or more portions, every 20-30 days (Deacon and Keast 1987, Kestemont and Philippart 1991). Few authors have been interested in the observation of morphology and the size of oocytes throughout the full development cycle. These authors also used different criteria for assessing the maturity of oocytes (Bagenal 1978, Kestemont and Philipart 1991). The measurements of oocytes and the data analyzed by other authors are given in Table 3 . The sizes of the previtellogenic oocytes and mature oocytes measured in the fish we studied and those reported by Burns (1976) were much smaller than the size of the oocytes in the pumpkinseed from Spain (Vila-Gispert et al. 2000). In our studies,

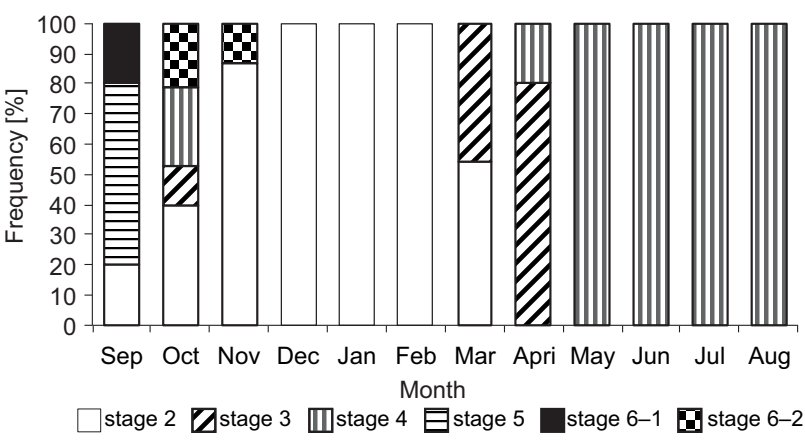

Fig. 7. Percentage contribution of gonads of respective maturity stages among males of pumpkinseed, Lepomis gibbosus, in consecutive months of the survey carried our in the warm-water canal of the Dolna Odra power plant

the oocytes at the stage of atresia present in the gonads were very few and were found in the fish caught between April and June. Such oocytes in the fish of the same species, but from southern Spain, were observed in September (Gutiérrez-Estrada et al. 2000).

Mature testes in males were found between the end of April and September, i.e., over a period much longer than that in which they occur in males from the natural habitat of the species and a month longer than that in which females are ready to spawn in the studied reservoir. According to Burns (1976), in the pumpkinseed from the natural range, multiplication of type $\mathrm{B}$ spermatogonia takes place between September and the beginning of May. In the pumpkinseed from the Dolna Odra power plant warm-water canal, the multiplication of type B spermatogonia also started in September (some males still had spawning gonads and some had spent gonads), but the primary spermatocytes (March) and the first spermatozoa (April) appeared earlier than in North America (Burns 1976). In the males from the population living in the canal with post-cooling water, the spawning gonads were observed for 5 months. In the fish of the studied species living in the natural range, the lobules were collapsed a month earlier (in late August) (Burns 1976). The spermatozoa remaining from the previous cycle do not interfere with the beginning of a new cycle. The subsequent reproductive cycles overlap and stage 1 is absent in adult males. In the pumpkinseed males living in the canal with the post-cooling water from the Dolna Odra power plant,

Table 3

The appearance and size of oocytes of pumpkinseed, Lepomis gibbosus, in respective months in different study areas

\begin{tabular}{|c|c|c|c|c|c|c|c|c|c|c|c|c|}
\hline \multicolumn{13}{|c|}{ Month } \\
\hline & Jan & Feb & Mar & Apr & May & Jun & Jul & Aug & Sep & Oct & Nov & Dec \\
\hline B & \multicolumn{4}{|c|}{ VLY Ø 270} & AV & & \multicolumn{3}{|c|}{ MAX SIZE } & \multicolumn{3}{|c|}{ VLY Ø 270} \\
\hline $\mathrm{D}$ & \multicolumn{3}{|c|}{ FV Ø 260} & AV Ø 350 & \multicolumn{5}{|c|}{ MAX SIZE Ø 909} & \multicolumn{3}{|c|}{ FV Ø 240} \\
\hline
\end{tabular}

$\mathrm{B}=$ Burns (1979), D = Domagała et al. (this study); VLY = very little yolk, AV = active vitellogenesis, MAX SIZE = oocytes reach a maximum size; $\mathrm{FV}=$ fat vacuoles. 
a renewal in the cycle of gonad development has been observed. In a few males in October, the cycle of gonad maturation and spermatozoa production was observed to restart. Simultaneously, large groups of degenerating cells were noted. Most probably the water temperature variation caused by the discharges of warm water from the power plant have initiated active spermatogenesis. Particularly numerous groups of degenerating cells were observed between September and February. These cells are supposed to have started maturation in the post-spawning season, stimulated by a short-time increase in the water temperature, and then to stop developing after the temperature decreased.

The presently reported study revealed the high reproductive potential of the pumpkinseed population established in the warm-water canal of the Dolna Odra power plant. The four-month long spawning season, small number of degenerating oocytes, fast regeneration of gonads after spawning, and good condition of the studied fish have confirmed that the canal provides very good living conditions for the species. The effect of the warm water discharged by the power plant decreases with the distance from the heat source. The pumpkinseed can be found predominantly in the warm-water canal and very few fish migrate below the merging point of the canal and the river. The predicted climatic changes leading to increased temperatures in the early spring and high temperatures in the summer (van Kleef et al. 2008) can change the situation and contribute to the spreading of this species. When occurring in greater numbers, the pumpkinseed may become a serious predator for fry of native fish species, including the economically important fish species (Welcomme 1988, Witkowski 1989). High abundance of the pumpkinseed can also lead to a decrease in the population of amphibians (Bosman 2003) and significantly decrease the amount of water invertebrates (van Kleef et al. 2008). According to Coop and Fox (2007), the spreading of this species depends on the age structure and size structure of its populations, properties of the catchment area (connections between the basins), human activity and temperature of the water in which the fish live. The efforts hitherto attempted to restrict the population of the pumpkinseed by reducing the depth of the basins inhabited by the fish have not been effective. It seems that currently not much can be done to limit the pumpkinseed population but it is desirable to continue the monitoring in the habitats where it occurs to control its further expansion.

\section{REFERENCES}

Aday D.D., Philipp D.P., Wahl D.H. 2006. Sex-specific life history patterns in bluegill (Lepomis macrochirus): interacting mechanisms influence individual body size. Oecologia 147 (1): 31-38. DOI: 10.1007/s00442-005-0242-x

Atkinson D. 1994. Temperature and organism size: a biological law for ectotherms. Book series: Advances in Ecological Research vol. 25.

Bagenal T.B. 1978. Aspects of fish fecundity. Pp. 75-131. In: Gerking S.D. (ed.) Ecology of freshwater fish production. Blackwell Scientific Publications, Oxford, UK.
Bertschy K.A., Fox M.G. 1999. The influence of age-specific survivorship on pumpkinseed sunfish life histories. Ecology 80 (7): 2299-2313. DOI: 10.1890/0012-9658(1999)080 [2299:TIOASS]2.0.CO;2

Bosman W. 2003. Het Rauwven, een "exotisch" ven in het beekdal van de Aa. [The Rauwven, an "exotic" marsh in the valley of the Aa river.] Ravon 5 (3): 33-36. [In Dutch.]

Breder C.M. 1936. The reproductive habits of the North American sunfishes (Family Centrarchidae). Zoologica 21 (102): 1-48.

Burns J.R. 1976. The reproductive cycle and its environmental control in the pumpkinseed, Lepomis gibbosus (Pisces: Centrarchidae). Copeia 1976 (3): 449-455. DOI: $10.2307 / 1443358$

Copp G.H., Fox M.G. 2007. Growth and life history traits of introduced pumpkinseed (Lepomis gibbosus) in Europe, and the relevance to its potential invasiveness. Pp. 289-306. In: Gherardi F. (ed.) Biological invaders in inland waters: Profiles, distribution, and threats. Springer, Netherlands. DOI: $10.1007 / 978-1-4020-6029-8 \_15$

Crivelli A.J., Mestre D. 1988. Life history traits of pumpkinseed Lepomis gibbosus introduced into the Camargue, a Mediterranean wetland. Archiv für Hydrobiologie 111 (3): 449-466.

Cucherousset J., Copp G.H., Fox M.G., Sterud E., van Kleef H.H., Verreycken H., Záhorská E. 2009. Life-history traits and potential invasiveness of introduced pumpkinseed Lepomis gibbosus populations in northwestern Europe. Biological Invasions 11 (9): 2171-2180. DOI: 10.1007/s10530-0099493-5

Danylchuk A.J., Fox M.G. 1994. Seasonal reproductive patterns of pumpkinseed (Lepomis gibbosus) populations with varying body size characteristics. Canadian Journal of Fisheries and Aquatic Sciences 51 (3): 490-500. DOI: 10.1139/f94-051

Danylchuk A.J., Fox M.G. 1996. Size- and age-related variation in the seasonal timing of nesting activity, nest characteristics, and female choice of parental male pumpkinseed sunfish (Lepomis gibbosus). Canadian Journal of Zoology $\mathbf{7 4}$ (10): 1834-1840. DOI: 10.1139/z96-206

Deacon L.I., Keast J.A. 1987. Patterns of reproduction in two populations of pumpkinseed sunfish, Lepomis gibbosus, with differing food resources. Environmental Biology of Fishes 19 (4): 281-296. DOI: 10.1007/BF00003229

De Magalhães A.L.B., Ratton T.F. 2005. Reproduction of a South American population of pumpkinseed sunfish Lepomis gibbosus (Linnaeus) (Osteichthyes, Centrarchidae): a comparison with the European and North American populations. Revista Brasileira de Zoologia 22 (2): 477-483. DOI: $10.1590 / \mathrm{S} 0101-81752005000200025$

Dembski S., Masson G., Monnier D., Wagner P., Pihan J.C. 2006. Consequences of elevated temperatures on life-history traits of an introduced fish, pumpkinseed Lepomis gibbosus. Journal of Fish Biology 69 (2): 331-346. DOI: 10.1111/j.1095-8649.2006.01087.x

Domagała J., Kondratowicz A. 2005. Porównanie wybranych wskaźników fizyko-chemicznych wód kanału doprowadzającego i odprowadzającego Elektrowni Dolna Odra w latach 
2000-2002. ["Comparison of selected physico-chemical indicators of water in inflowing and outflowing channels of Dolna Odra power plant in 2000-2002 years."] Zeszyty Naukowe Wydziału Budownictwa i Inżynierii Środowiska; Politechnika Koszalińska; Seria: Inżynieria Środowiska 22: 741-750. [In Polish.]

Domagała J., Kirczuk L., Pilecka-Rapacz M. 2013. Annual development cycle of gonads of Eurasian ruffe (Gymnocephalus cernuus L.) females from lower Odra River sections differing in the influence of cooling water. Journal of Freshwater Ecology 28 (3): 423-437. DOI: 10.1080/02705060.2013.777855

Domagala J., Pilecka-Rapacz M. 2007. Charakterystyka wód pochłodniczych Elektrowni Dolna Odra w latach 2004-2006. ["The profile of post-cooling water from Dolna Odra power plant 2004-2006."] Zeszyty Naukowe Wydziału Budownictwa i Inżynierii Środowiska; Politechnika Koszalińska; Seria: Inżynieria Środowiska 23: 751-760. [In Polish.]

Fox M.G. 1994. Growth, density, and interspecific influences on pumpkinseed sunfish life histories. Ecology 75 (4): 1157-1171. DOI: 10.2307/1939439

Fox M.G., Crivelli A.J. 1998. Body size and reproductive allocation in a multiple spawning centrarchid. Canadian Journal of Fisheries and Aquatic Sciences 55 (3): 737-748. DOI: 10.1139/f97-269

Fox M.G., Crivelli A.J. 2001. Life history traits of pumpkinseed (Lepomis gibbosus) populations introduced into warm thermal environments. Archiv für Hydrobiologie 150 (4): 561-580.

Fox M.G., Keast A. 1991. Effect of overwinter mortality on reproductive life history characteristics of pumpkinseed (Lepomis gibbosus) populations. Canadian Journal of Fisheries and Aquatic Sciences 49 (9): 1792-1799. DOI: 10.1139/f91-211

Gutiérrez-Estrada J.C., Pulido-Calvo I., Fernaádez-Delgado C.G. 2000. Age-structure, growth and reproduction of the introduced pumpkinseed (Lepomis gibbosa, L. 1758) in a tributary of the Guadalquivir River (southern Spain). Limnetica 19: 21-29.

Heese T., Przybyszewski C. 1985. Bass słoneczny, Lepomis gibbosus (L., 1758), (Pisces, Centrarchidae) w wodach Dolnej Odry. [Pumpkinseed sunfish, Lepomis gibbosus (L., 1758), (Pisces, Centrarchidae) in the waters of the lower Odra River.] Przegląd Zoologiczny 29 (4): 515-519. [In Polish.]

Holčik J. 1995. Lepomis gibbosus (Linnaeus, 1758). In: Baruš V., Oliva O. (eds.) Mihulovci Petromyzontes a ryby Osteichthyes (2). [Cyclostomes Petromyzontes and fishes Osteichthyes (2).] Academia, Praha, Czech Republic. [In Czech.]

Hunter J.R., Goldberg S.R. 1980. Spawning incidence and batch fecundity in northern anchovy, Engraulis mordax. Fishery Bulletin 77 (3): 641-652.

Kestemont P., Philippart J.-C. 1991. Considérations sur la croissance ovocytaire chez les poissons à ovogenèse synchrone et asynchrone. Belgian Journal of Zoology 121 (1): 87-98.
Klaar M., Copp G.H., Horsfield R. 2004. Autumnal habitat use of non-native pumpkinseed Lepomis gibbosus and associations with native fish species in small English streams. Folia Zoologica 53 (2): 189-202.

Lever C. 1977. The naturalized animals of the British Isles. Hutchinson, London, UK.

Miller H.C. 1963. The behavior of the pumpkinseed sunfish Lepomis gibbosus (Linneaus), with notes on the behavior of the other spiecies of Lepomis and the pigmy sunfish, Elassoma evergladei. Behaviour 22 (1-2): 88-151.

Mischke C.C., Morris J.E. 2002. Water temperature influences on survival and growth. Pp. 29-30. In: Morris J.E., Mischke C.C., Garling D.L. (eds.) Sunfish culture guide. NCRAC Culture Series No. 102. North Central Regional Aquaculture Center Publications Office, Iowa State University, Ames, IA, USA.

Neophitou C., Giapis A.J. 1994. A study of the biology of pumpkinseed (Lepomis gibbosus (L.)) in Lake Kerkini (Greece). Journal of Applied Ichthyology 10 (2-3): 123-133. DOI: 10.1111/j.1439-0426.1994.tb00151.x

Santos R.E., Silva T.P., Chehayeb I., de Magalhães A.L.B. 2012. Reproduction of the non-native fish Lepomis gibbosus (Perciformes: Centrarchidae) in Brazil. Revista de Biología Tropical 60 (3): 1327-1334.

Sakun O.F., Buckaâ N.A. [Butskaya N.A.] 1963. Opredelenie stadij zrelosti i izučenie polovyh ciklov ryb. [Determination of maturity stages and studies on sexual cycles of fishes.] Izdatel'stvo Rybnoe Hozâjstvo, Moskva, Russia. [In Russian.]

Tomeček J., Kováč V., Katina S. 2007. The biological flexibility of the pumpkinseed: A successful colonizer throughout Europe. Pp. 307-336. In: Gherardi F. (ed.) Biological invaders in inland waters: Profiles, distribution, and threats. Springer, Netherlands. DOI: 10.1007/978-1-4020-6029$8 \_16$

van Kleef H., van der Velde G., Leuven R.S.E.W., Esselink H. 2008. Pumpkinseed sunfish (Lepomis gibbosus) invasions facilitated by introductions and nature management strongly reduce macroinvertebrate abundance in isolated water bodies. Biological Invasion 10 (8): 1481-1490. DOI: 10.1007/s10530-008-9220-7

Vila-Gispert A., Moreno-Amich R. 1998. Seasonal abundance and depth distribution of Belnnius fluviatilis and introduced Lepomis gibbosus, in Lake Banyoles (Catalonia, Spain). Hydrobiologia 386 (1-3): 95-101. DOI: 10.1023/A: 1003522931405

Vila-Gispert A., Moreno-Amich R. 2000. Fecundity and spawning mode of three introduced fish species in Lake Banyoles (Catalunya, Spain) in comparison with other localities. Aquatic Sciences 61 (2): 154-166. DOI: 10.1007/ s000270050004

Villeneuve F., Copp G.H., Fox M.G., Stakėnas S. 2005. Interpopulation variation in growth and life-history traits of the introduced sunfish, pumpkinseed Lepomis gibbosus, in southern England. Journal of Applied Ichthyology 21 (4): 275-281. DOI: 10.1111/j.1439-0426.2005.00679.x

Vooren C.M. 1972. Ecological aspects of the introduction of fish species into natural habitats in Europe, with special ref- 
erence to the Netherlands. Journal of Fish Biology 4 (4): 565-583. DOI: 10.1111/j.1095-8649.1972.tb05702.x

Welcomme R.L. 1988. International introductions of inland aquatic species. FAO Fisheries Technical Paper No. 294. FAO, Rome.

Witkowski A. 1979. Nowe stanowisko bassa słonecznego, Lepomis gibbosus (L.) (Osteichthyes: Centrarchidae) w dorzeczu Baryczy. [New locality of sunfish, Lepomis gibbosus (L.) (Osteichthyes: Centrarchidae) in catchment area of the Barycz River.] Fragmenta Faunistica 25 (2): 15-19. [In Polish.]

Witkowski A. 1989. Introdukowane ryby w polskich wodach i ich wpływ na środowisko. [Fish introduced to Polish waters and their impact on environment.] Przegląd Zoologiczny 33 (4): 583-598. [In Polish.]

Witkowski A. 2002. Introduction of fishes into Poland: benefaction or plague? Nature Conservation 59 (2): 41-52.
Witkowski A., Grabowska J. 2012. The non-indigenous freshwater fishes of Poland: Threats for native ichthyofauna and consequence for fishery: A review. Acta Ichthyologica et Piscatoria 42 (2): 77-87.

Witkowski A., Kotusz J., Przybylski M., Marszal L., Heese T., Amirowicz A., Buras P., Kukuła K. 2004. Origin, species composition and present degree of threat to fish fauna in the Vistula and Oder river systems. Archives of Polish Fisheries 12 (Suppl. 2): 7-20.

Zięba G., Fox M.G., Copp G.H. 2010. The effect of elevated temperature on spawning of introduced pumpkinseed Lepomis gibbosus in Europe. Journal of Fish Biology 77 (8): 1850-1856. DOI: 10.1111/j.1095-8649.2010.02778.x

Received: 23 January 2014 Accepted: 15 May 2014 Published electronically: 30 June 2014 